\title{
Occurrence of Methicillin Resistant Staphylococcus Aureus in Emerging Tertiary Care Hospital, Veraval, Gujarat, India
}

\section{Sujithra M1, Vanik D², Sivaraman GK${ }^{3 *}$ and Koya KM4}

${ }^{1}$ Departement of biotechnology, Dr. Rangarajan Dr. Sakunthala Engineering College, India

2Department of Microbiology, India

${ }^{3}$ Department Fisheries Technology, India

${ }^{4}$ Department of Fisheries Resources, India

*Corresponding author: Gopalan Krishnan Sivaraman, Department Fisheries Technology, Principal Scientist, ICARCIFT, MFB Division, Matsyapuri Post, Willingdon Island, Cochin- 682029, Kerala, India, Tel: +91-484-2412384(0); Email: gkshivraman@gmail.com

\section{Abstract}

The present study was carried out to monitor the incidence of MRSA as an emerging pathogen in health care setting. In total of 36 clinical samples from men, women and children and also hand swabs of nursing staff and surrounding environment of GirSomnath District, Veraval Civil Hospital, Gujarat were collected and examined for the presence of MRSA. The collected samples were screened for the presence of MRSA and assessing their antimicrobial susceptibility testing, minimum inhibitory concentration as per CLSI (2017) guideline. The incidence rate of MRSA was found as $52.78 \%$. The results indicate that the highest level of resistance was found to Penicillin (100\%) and the least level of resistance was found to Tigecycline (4\%). About $24 \%$ isolates were positive for mecA gene. The lack of health care facility (antimicrobial testing), poor hygienic practices, and awareness among the patient and healthcare workers may be plays a significant role in the presence of MRSA in the health care setting.

Keywords: Minimum Inhibitory Concentration; MRSA; Opportunistic Pathogen; Gram-Positive Bacteria; Staphylococcus Aureus

\section{Introduction}

Worldwide infections are the most important cause for mortality in humans and bacteria are more severe in developing and under-developed countries [1]. Pathogens are even more infectious in nature due to indiscriminate use of antibiotics. Staphylococcus aureus is a common inhabitant of human skin and noses of $25 \%$ of healthy 
people as well as animals and do not cause infections among healthy individuals as carrier [2]. As an opportunistic pathogen $S$. aureus can cause a broad range of infections including mild skin infections such as impetigo and folliculitis to invasive diseases like wound infections, osteomyelitis, bacteraemia with metastatic complications, and toxin mediated diseases like food poisoning, toxic shock syndrome, scaled skin syndrome [3-5]. It is ubiquitous Gram-positive, catalase positive facultative anaerobic cocci [6]. The genus Staphylococcus comprises of 47 recognized species and 21 subspecies out of which three species viz., S. aureus, $S$. saprophyticus and $S$. epidermidis are associated with hospital-acquired infections. In addition to these three species, other staphylococcal species such as $S$. warnerii, S. scuiri, $S$. hemolyticus and $S$. lugdunensis etc., is being reported in the secondary bacterial infections either in post-operative or among immune compromised individuals [7].

Methicillin was introduced as new $\beta$-lactam antibiotics in 1950 to overcome penicillin resistance among S.aureus. Later in 1961, methicillin resistant Staphylococcus aureus (MRSA) was reported in United Kingdom which was resistant to most of the commonly prescribed antibiotics such as penicillin, cephalosporins and carbapenems [8]. Being a nosocomial pathogen [9], MRSA are frequently associated with ventilator associated infections and surgical site infections making treatment more difficult $[10,11]$. Emergence of MRSA has increased all over the world and is a major challenge to hospital [12]. Colonization and infection rates of MRSA are reported in $0.8 \%$ of US population with $15 \%$ increase in Alberta between 2005 and 2008 and higher rates in Canada over the past decade $[6,13,14]$. The incidence of MRSA is $25 \%$ in Western part of India $50.18 \%$ in Central India and 70\% in South India and overall incidence rate was ranged between 8 and 71\% [15-19]. The incidence rate of MRSA has increased in the past 20 years, accompanied by a rise in antibiotic-resistant strains. Recently vancomycin- resistant strains have also been detected around the world [20]. Infections caused by MRSA often fail to respond to standard treatment, resulting in prolonged illness, higher health care expenditures, and a greater risk of death. Poor infection control practices, inadequate sanitary conditions and inappropriate food-handling encourage the further spread of antimicrobial resistance [21]. Region-wise knowledge of antibiotic resistance patterns and resistance genes in the area is of paramount importance for surveillance and control of the spread of antibiotic resistance as well as for instituting appropriate therapy and judicious antibiotic usage. The present study was undertaken to determine the prevalence and molecular characterization of MRSA isolated from various swabs of patient's being treated in the civil hospital, Veraval, Gujarat and to establish resistance pattern among the isolates of MRSA.

\section{Materials and Methods}

\section{Sample Collection}

This study was carried for a three month period from January 2017 to March 2017 in civil hospital at Veraval, Gujarat. Different clinical samples (36) viz., 9 samples each of rectal swab (EC $1 \mathrm{~W}$, EC $2 \mathrm{~W}$ and EC $3 \mathrm{~W}$ ) hand swab (EC $1 \mathrm{M}$, EC 2 M, EC 3 M, EC 1 C, EC 2 C, EC 3 C and EC $4 \mathrm{C}$ ), wound swab and urine sample (Urine sample Women) were collected from patients including men, women and children. Sampling also comprised of hand swabs of Staff Nurses (HP1- HP5) and surrounding environment which encompassed operation theatre (OT1- OT5), floor sample of hospital (FS1- FS4) and toilet samples (TFS1- TFS9) were collected (Table 1). All the samples were screened for MRSA as per standard protocol using MRSA II agar plate (Difco, USA) and mecA gene coding for methicillin resistance and nuc gene for coagulase production were amplified by Polymerase Chain Reaction (PCR) [22].

\begin{tabular}{|c|c|c|c|c|}
\hline Marker & \multirow{2}{*}{ Target } & Primer & Oligo sequence $\mathbf{( 5}^{\prime} \rightarrow \mathbf{3}^{\prime} \mathbf{)}$ & $\begin{array}{c}\text { Primer } \\
\text { concentration }\end{array}$ \\
\hline $\begin{array}{c}\text { Gene specific to } \\
\text { Staphylococcus genus }\end{array}$ & \multirow{2}{*}{ 16S rRNA gene } & Staph756F & AAC TCT GTT ATT AGG GAA GAA CA & $0.12 \mu \mathrm{M}$ \\
\cline { 3 - 5 } $\begin{array}{c}\text { Virulence gene encoding } \\
\text { thermonuclease }\end{array}$ & \multirow{2}{*}{ Suc gene } & Staph750R & CCA CCT TCC TCC GGT TTG TCA CC & $0.12 \mu \mathrm{M}$ \\
\cline { 3 - 5 } $\begin{array}{c}\text { Gene responsible for } \\
\text { methicillin resistance }\end{array}$ & \multirow{2}{*}{ mecA gene } & GucR & AGC CATT GCAT GGT GAT ACG GTT & $0.04 \mu \mathrm{M}$ \\
\cline { 3 - 5 } & mecF & GTA GAA ATG ACT GAA AAC TAA AGC & $0.04 \mu \mathrm{M}$ \\
\hline
\end{tabular}

Table 1: PCR target and primers used for the multiplex PCR. 


\section{International Journal of Zoology and Animal Biology}

\section{MRSA Strains Isolation and Identification}

The clinical isolates were identified as S.aureus using standard biochemical methods [23]. Isolation was done based on colony morphology on Baird Parker agar (Oxoid, UK) supplemented with $1 \mathrm{ml} 50 \%$ egg yolk emulsion and $1 \%$ potassium tellurite solution with $48 \mathrm{hrs}$ of incubation. Subsequently, MRSA confirmation was done on readymade plates of MRSA II (Difco) within 24 hours of incubation at $35^{\circ} \mathrm{C}$. Well isolated colonies were streaked on to Tryptic Soy Agar plate for isolation and further purification. Methicillin resistance was confirmed both phenotypically by disc diffusion testing and genotypically multiplex PCR [22].

The antimicrobial susceptibility of $S$. aureus isolates to 24 antibiotics namely, penicllin-G (P), $10 \mu \mathrm{g}$ azithromycin (AZM) $15 \mu \mathrm{g}$, erythromycin (E) $15 \mu \mathrm{g}$, clarithromycin (CLR) $15 \mu \mathrm{g}$, linezolid (LZ) $30 \mu \mathrm{g}$, cotrimoxazole (COT) $25 \mu \mathrm{g}$, vancomycin (VA) $30 \mu \mathrm{g}$, cefoxitin (CX) 30 $\mathrm{\mu g}$, ciprofloxacin
(CIP) $5 \mu \mathrm{g}$, gatifloxacin (GAT) $5 \mu \mathrm{g}$,ofloxacin (OF) $5 \mu \mathrm{g}$, clindamycin (CD) $2 \mu \mathrm{g}$, tigecycline (TGC) $15 \mu \mathrm{g}$, moxifloxacin(MO) $5 \mu \mathrm{g}$, gentamicin (GEN)10 $\mu \mathrm{g}$, rifampicinb (RIF) $5 \mu \mathrm{g}$, lomefloxacin (LOM)10 $\mu \mathrm{g}$, norfloxacin (NX)10 $\mu \mathrm{g}$, novobiocin (NV) $30 \mu \mathrm{g}$, teicoplanin (TEI) $30 \mu \mathrm{g}$, nitrofurantoin (NIT) $300 \mu \mathrm{g}$, pristinomycin (RP) $15 \mu \mathrm{g}$ ampicillin/sulbactam (A/S) 10/10 $\mu \mathrm{g}$, piperacillin/tazobactam (PIT) 100/10 $\mu$ g (Dodeca Staphylococci-1 and 2, HiMedia, Mumbai) were carried out by disc diffusion method (Bauer et al., 1966) on Mueller Hinton agar with $4 \% \mathrm{NaCl}$ and incubated at $37^{\circ} \mathrm{C}$ for 18- $24 \mathrm{hrs}$ (Figure 1). The inhibition zones were measured and categorized as susceptible, intermediately resistant or and resistant. Multi drug resistant (MDR) staphylococci were those isolates that were resistant to penicillin along with at least 3 other classes of antibiotics. The tests were performed and the results were interpreted as per CLSI guidelines [24].

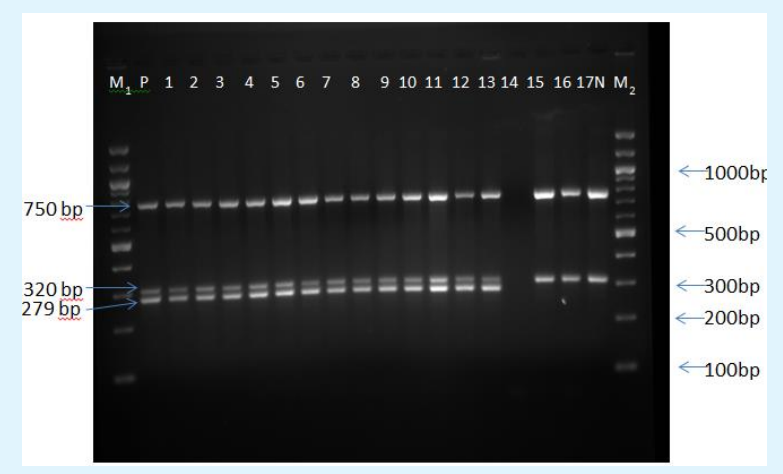

Lane no. 3- 17 Clinical samples; P: Positive Control ATCC 43300 MRSA; N: Negative Control ATCC 25923 MSSA; M1 \& M2: DNA ladder 100 bp; 278bp: Nuc, 320bp: mecA gene; 750bp: Staphylococci

Figure 1: Multiplex PCR assay for the confirmation of methicillin resistant Staphylococci from the clinical setting.

\section{Minimum Inhibitory Concentration (MIC)}

S.aureus strains were cultured in Brain heart infusion broth and the concentration was adjusted to $0.5 \mathrm{Mc}$ Farland's standard, and then the culture was spread over MHA with $4 \% \mathrm{NaCl}$. MIC was determined with MIC test strip (HiMedia, Mumbai) for antibiotics that are commonly used for staphylococcal infections such as methicillin A $(240-0.01 \mu \mathrm{g} / \mathrm{ml})$, methicillin B (4-0.001 $\left.\mu \mathrm{g} . \mathrm{ml}^{-1}\right)$, penicillin $\left(0.002-32 \mu \mathrm{g} \cdot \mathrm{ml}^{-1}\right)$, oxacillin $(0.016-256$ $\left.\mu \mathrm{g} . \mathrm{ml}^{-1}\right)$ vancomycin $\left(0.016-256 \mu \mathrm{g} \cdot \mathrm{ml}^{-1}\right)$, gentamicin (0.016-256 $\left.\mu \mathrm{g} \cdot \mathrm{ml}^{-1}\right)$ and ciprofloxacin (0.002-32 $\left.\mu \mathrm{g} \cdot \mathrm{ml}^{-1}\right)$. The results were interpreted as per CLSI guidelines.

\section{Molecular Typing of MRSA}

DNA was isolated from staphylococci using GenElute bacterial genomic DNA kit (Sigma-Aldrich) according to manufacturer's instructions. Multiplex Multiplex PCR (SureCycler 8000, Agilent, USA) was set in $20 \mu \mathrm{l}$ reaction mixture comprising $5 \mu \mathrm{l}$ of template DNA, $2.5 \mathrm{mM} \mathrm{MgCl}$, $0.2 \mathrm{mM}$ dNTPs mix, primers (Table 1) and Taq DNA polymerase. The PCR program comprised of initial denaturation temperature of $94^{\circ} \mathrm{C}$ for $5 \mathrm{~min}$; 10 cycles of $94^{\circ} \mathrm{C}$ for $40 \mathrm{sec}, 68^{\circ} \mathrm{C}$ for $40 \mathrm{sec}$, and $72^{\circ} \mathrm{C}$ for $1 \mathrm{~min} ; 25$ cycles of $94^{\circ} \mathrm{C}$ for $1 \mathrm{~min}, 58^{\circ} \mathrm{C}$ for $1 \mathrm{~min}$, and $72^{\circ} \mathrm{C}$ for 2 $\mathrm{min}$; and the final extension at $72^{\circ} \mathrm{C}$ for $10 \mathrm{~min}$. Agarose gel electrophoresis was performed for separation of 
amplicons in $2 \%$ agarose gel containing ethidium bromide $\left(0.5 \mu \mathrm{g} \cdot \mathrm{ml}^{-1}\right)$ followed by capturing of images using gel documentation system (Bio Rad, USA). The positive control strain of MRSA ATCC 43300 and negative control strain of MSSA ATCC 25923 was used for quality control (Figure 2).

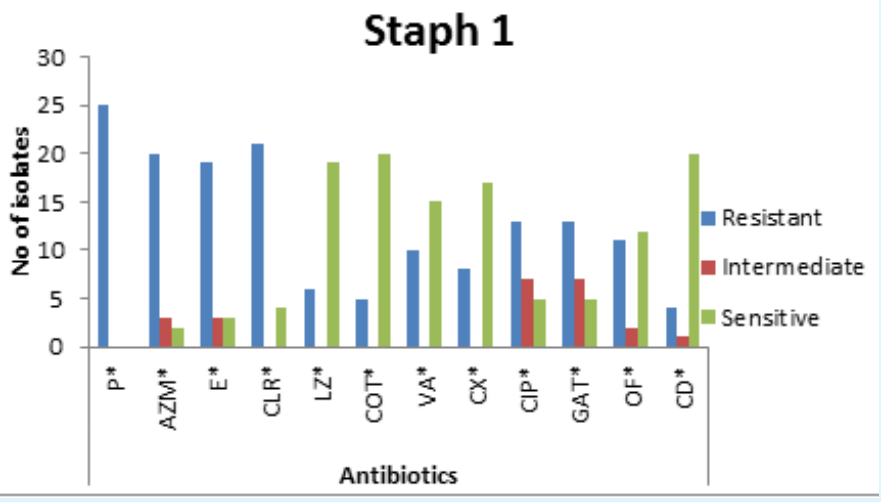

Figure 2: Antibiotic resistance pattern of the MRSA strains with Dodecca Staphylococci-1(HiMedia, Mumbai).

\section{Results and Discussion}

The present study was carried out to monitor MRSA incidence in Veraval Civil Hospital for a period of 3 months during January 2017 to March 2017. Out of total 36 samples, 19 (52.78\%) samples were found positive for MRSA, 3 toilet floor samples, 7 staff hand swab, 3 operation theatre samples, 1 urine and 1 hospital sample were also positive for MRSA. Similar resistance pattern was observed by Rubali, et al. [17] wherein 58.33\% coagulase positive MRSA were isolated from Tertiary care hospital in Central India. According to and Fombda, et al. [25] the prevalence rate of MRSA in a tertiary care hospital was 33\% and 34.2\% in Mumbai and Jammu and Kashmir, respectively, which was slightly lower than the present study (52.78\%). Varied incidence rate of MRSA was reported around different part of the globe in the health care settings viz., $21-30 \%$ in Nigeria, Kenya and Camroon and incidence rate below $10 \%$ were reported in Algeria, Tunisia and Malta Kesah, et al. [26]. The prevalence rate in Netherland and Switzerland ranged from 2 to $15 \%$ whereas in Japan and Hong Kong the prevalence rates were as high as 70\% [27]. Thus, the prevalence of MRSA varies globally and it is further suggested that the higher incidence of MRSA is due to indiscriminate use of antimicrobial agents, improper prescription of antibiotics and limited hygienic facilities available with the health care settings. Furthermore Fridkin and Gaynes, et al. [28] suggested that the rate of MRSA acquisition may be directly proportional to duration of stay in hospital.

The antimicrobial susceptibilities of confirmed MRSA isolates were evaluated against 24 commonly available antimicrobial agents as per CLSI 2015 standards (Table 2). The MRSA isolates exhibited cent percent resistance towards penicillin followed by clarithromycin, aziothromycin, pristinimycin, erythromycin and lomefloxacin. Fombda, et al. [25] also reported highest resistance of MRSA to penicillin followed by erythromycin, clindamycin and cotrimaxazole, but susceptibility towards vancomycin and gentamycin. Similarly, Vysakh, et al. [29] also reported $81 \%$ of MRSA resistant towards penicillin, followed by erythromycin and cefoxitin. In the current study, isolates showed least level of resistance to clindamycin and tigecycline. The intermediate level of resistance was found among MRSA isolates to teicoplanin, ciprofloxacin and gatifloxacin, moxifloxacin, norfloxacin, lomefloxacin and nitroflurantin, aziothromycin and erythromycin and ampicillin/sublactum. The isolates showed cent percent sensitivity to rifampicin and novobiocin followed by tigecycline, nitroflurantoin, cotrimaxazole, clindamycin, linezolid and cefoxitin. 


\section{International Journal of Zoology and Animal Biology}

\begin{tabular}{|c|c|c|c|}
\hline \multirow{2}{*}{ Antibiotics } & \multicolumn{3}{|c|}{ Susceptibility of $S$. aureus isolates based on disc diffusion assay } \\
\hline & Resistance & Intermediate & Sensitive \\
\hline Penicillin $(\mathrm{P})$ & $25(100.00 \%)$ & - & - \\
\hline Aziothromycin(AZM) & $20(80.00 \%)$ & $3(12.00 \%)$ & $2(8.00 \%)$ \\
\hline Erythromycin (E) & $19(76.00 \%)$ & $3(12.00 \%)$ & $3(12.00 \%)$ \\
\hline Clarithromycin (CLR) & $21(84.00 \%)$ & - & $4(16.00 \%)$ \\
\hline Linezolid (LZ) & $6(24.00 \%)$ & - & $19(76.00 \%)$ \\
\hline Co-Trimoxazole (COT) & $5(20.00 \%)$ & - & $20(80.00 \%)$ \\
\hline Vancomycin (VA) & $10(40.00 \%)$ & - & $15(60.00 \%)$ \\
\hline Cefoxitin (CX) & $8(32.00 \%)$ & - & $17(68.00 \%)$ \\
\hline Ciprofloxacin (CIP) & $13(52.00 \%)$ & $7(28.00)$ & $5(20.00 \%)$ \\
\hline Gatifloxacon (GAT) & $13(52.00 \%)$ & $7(28.00)$ & $5(20.00 \%)$ \\
\hline Ofloxacin (OF) & $11(44.00 \%)$ & $2(8.00 \%)$ & $12(48.00 \%)$ \\
\hline Clindamycin (CD) & $4(16.00 \%)$ & $1(4.00 \%)$ & $20(80.00 \%)$ \\
\hline Tigecycline (TGC) & $1(4.00 \%)$ & $2(8.00 \%)$ & $22(88.00 \%)$ \\
\hline Moxifloxacin (MO) & $9(36.00 \%)$ & $6(24.00 \%)$ & $10(40.00 \%)$ \\
\hline Gentamycin (GEN) & $12(48.00 \%)$ & - & $13(52.00 \%)$ \\
\hline Rifampicin (RIF) & - & - & $25(100.00 \%)$ \\
\hline Lomefloxacin (LOM) & $17(68.00 \%)$ & $4(16.00 \%)$ & $4(16.00 \%)$ \\
\hline Norfloxacin (NX) & $8(32.00 \%)$ & $5(20.00 \%)$ & $12(48.00 \%)$ \\
\hline Novobiocin (NV) & - & - & $25(100.00)$ \\
\hline Teicoplanin (TEI) & - & $9(36.00 \%)$ & $16(64.00 \%)$ \\
\hline Nitroflurantin (NIT) & - & $4(16.00 \%)$ & $21(84.00 \%)$ \\
\hline Pristinomycin (RP) & $20(80.00 \%)$ & - & $5(20.00 \%)$ \\
\hline Ampicillin/Sublactum (A/S) & $7(28.00 \%)$ & $2(8.00 \%)$ & $16(64.00 \%)$ \\
\hline Piperacillin/Tazobactum (PIT) & $9(36.00 \%)$ & - & $16(64.00 \%)$ \\
\hline
\end{tabular}

Antibiotic classes: P: Penicillin; Macrolides: E \& CLR; Oxazolidinones: LZ; Sulfonamides: COT; Azalides: AZM; Fluoroquinilones: CIP, GAT, OF, LOM, MO \& NX; Lincosamide: CD; Cephems: CX; Aminoglycosides: VA, GEN \& NIT, Rifampicin: RIF; Glycylcyclines: TGC; Glycopeptides: TEI; Aminocoumarin: NV; Streptogramin: RP; Beta lactam \& Beta lactam inhibitor: A/S; PIT.

Table 2: Antibiotic susceptibility of the MRSA isolates by disc diffusion method.

In this study, $63.89 \%$ MRSA strains were multidrug resistant (Figures $3 \& 4$ ) and the presence of MDR- CPS MRSA may occur in the form of infection and or asymptomatic carrier's. The multi-drug resistance was defined as resistance to 3 or more different classes of antimicrobials in addition to the penicillin. Several studies on MRSA revealed that the hygienic- sanitary profile, personal hygienic practices and habits, raising the risk of cross contamination in the handled food [30]. S. aureus has developed multidrug resistance worldwide and indicates that as potential hazards to human health [31]. Recent reports revealed that MDR bacteria can be transferred from the human to environment and to animal [32]. It is further suggesting that significant awareness among the public must be made about the presence of MDR-CPS- MRSA. Tiwari, et al. [33] reported that $72.1 \%$ of MRSA were multi drug resistant in a tertiary hospital of northern India. Whereas, Styers, et al. [34] reported of multi-drug resistance of MRSA in some workers of USA. The widespread use of antibiotics has provoked an exponential increase in the incidence of antibiotic resistant and multi-drug resistant strains threaten the effective prevention and treatment of infections [35]. 


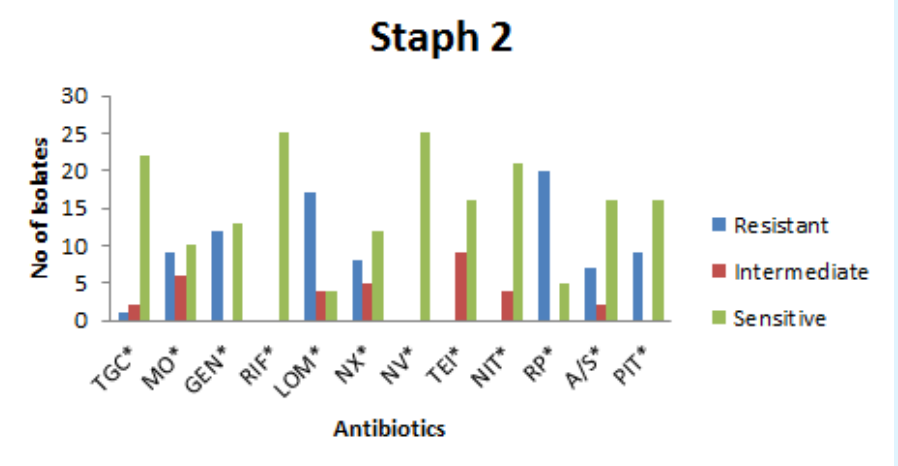

Figure 3: Antibiotic resistance pattern of the MRSA strains with Dodecca Staphylococci-2 (HiMedia, Mumbai).

4.a

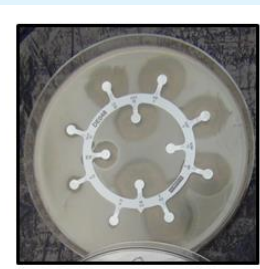

4.c

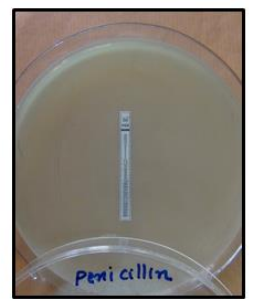

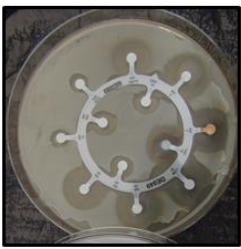

4.d

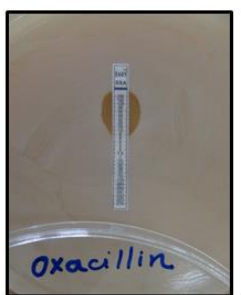

Figure 4: Antibiotic resistance of MRSA strains with Dodecca Staphylococci- 1 and 2 (4a and b) and Minimum Inhibitory Concentration using MIC strips (HiMedia, Mumbai) for penicillin (4c) and oxacillin (4d).

In the present study, values of MIC of routinely used antimicrobial agents used in tertiary hospitals were with for the test MRSA isolates and found that most of these isolates showed a higher MIC level of $\geq 256 \mu \mathrm{g}$. $\mathrm{ml}^{-1}$. From the rectal swabs, hand swabs of the patients and staff and floors showed a methicillin MIC of $\geq 240 \mu \mathrm{g} \cdot \mathrm{ml}^{-1}$. Also shows a higher level of resistance to the methicillin $B$, Gentamicin, ciprofloxacin, oxacillin, vancomycin and penicillin with $\geq 256 \mu \mathrm{g} \cdot \mathrm{ml}^{-1}$ irrespective of the types of samples examined from the patients during this study and it could pose a serious threat to public health as this affects infection control and further may also lead to dissemination MRSA strains. Hence, effective infection control measures and regular monitoring studies should be conducted in health care facilities for MRSA and other drug resistant bacteria.

Out of 19 isolates $(52 \%),(48 \%)$ and $(8 \%)$ were found to be resistant to methicillin, gentamycin and ciprofloxacin, respectively, with MIC of $\leq 1 \mu \mathrm{g} \cdot \mathrm{ml}^{-1}$. Exactly, $12 \%$ of isolates were resistant to oxacillin (MIC level of $\leq$ $2 \mu \mathrm{g} \cdot \mathrm{ml}^{-1}$ ). Majority of the isolates (18; 72\%) were resistant to vancomycin with $\mathrm{MIC} \leq \mu \mathrm{g} \cdot \mathrm{ml}^{-1}$. Moreover, all the MRSA isolates were resistant to Penicillin (Tables 3 \& 4). 
International Journal of Zoology and Animal Biology

\begin{tabular}{|c|c|c|c|c|c|c|c|}
\hline Samples & $\begin{array}{c}\text { Methicillin } \\
\text { A }\end{array}$ & \begin{tabular}{|c|} 
Methicillin \\
B
\end{tabular} & Gentamicin & Ciprofloxacin & Oxacillin & Vancomycin & Penicillin \\
\hline Rectal swabs EC 1 W & $\geq 240$ & $\geq 4$ & $\geq 256$ & $\mathrm{R}$ & $\mathrm{R}$ & $\geq 256$ & $\mathrm{R}$ \\
\hline EC $3 \mathrm{M}$ & $\mathrm{R}$ & $\geq 4$ & $\mathrm{R}$ & $\mathrm{R}$ & $\mathrm{R}$ & $\geq 256$ & $\mathrm{R}$ \\
\hline Wound swab EC 2 W & $\mathrm{R}$ & $\mathrm{R}$ & $\mathrm{R}$ & $\mathrm{R}$ & $\mathrm{R}$ & $\geq 256$ & $\mathrm{R}$ \\
\hline Hand swabs EC $1 \mathrm{C}$ & $\geq 240$ & $\geq 4$ & $\geq 256$ & $\geq 256$ & $\mathrm{R}$ & $\geq 256$ & $\mathrm{R}$ \\
\hline EC $1 \mathrm{M} \mathrm{A}$ & $\mathrm{R}$ & $\mathrm{R}$ & $\mathrm{R}$ & $\mathrm{R}$ & $\mathrm{R}$ & $\geq 256$ & $\mathrm{R}$ \\
\hline EC $1 \mathrm{M} \mathrm{B}$ & $\geq 240$ & $\geq 4$ & $\geq 256$ & $\mathrm{R}$ & $\mathrm{R}$ & $\geq 256$ & $\mathrm{R}$ \\
\hline EC $1 \mathrm{M} \mathrm{R}$ & $\geq 240$ & $\geq 4$ & $\geq 256$ & $\mathrm{R}$ & $\mathrm{R}$ & $\geq 256$ & $\mathrm{R}$ \\
\hline EC 2 C & $\geq 240$ & $\geq 4$ & $\mathrm{R}$ & $\mathrm{R}$ & $\mathrm{R}$ & $\geq 256$ & $\mathrm{R}$ \\
\hline EC 4 C & $\geq 240$ & $\geq 4$ & $\geq 256$ & $\geq 32$ & $\geq 256$ & $\geq 256$ & $\mathrm{R}$ \\
\hline EC $3 \mathrm{~W}$ & $\geq 240$ & $\geq 4$ & $\geq 256$ & $\geq 32$ & $\geq 256$ & $\geq 256$ & $\mathrm{R}$ \\
\hline $\begin{array}{l}\text { Toilet Floor sample } \\
\text { FS } 2 \text { C }\end{array}$ & $\geq 240$ & $\geq 4$ & $\mathrm{R}$ & $\mathrm{R}$ & $\geq 256$ & $\geq 256$ & $\mathrm{R}$ \\
\hline TFS $2 \mathrm{~B}$ & $\geq 240$ & $\geq 4$ & $\mathrm{R}$ & $\geq 32$ & $\geq 256$ & $\geq 256$ & $\mathrm{R}$ \\
\hline TFS 7 & $\geq 240$ & $\geq 4$ & $\mathrm{R}$ & $\mathrm{R}$ & $\mathrm{R}$ & $\geq 256$ & $\mathrm{R}$ \\
\hline Staff hand swab HP 1 & $\geq 240$ & $\geq 4$ & $\mathrm{R}$ & $\mathrm{R}$ & $\mathrm{R}$ & $\geq 256$ & $\mathrm{R}$ \\
\hline HP 2 & $\geq 240$ & $\geq 4$ & $\geq 256$ & $\mathrm{R}$ & $\geq 256$ & $\geq 256$ & $\mathrm{R}$ \\
\hline HP 3 A & $\geq 240$ & $\geq 4$ & $\geq 256$ & $\mathrm{R}$ & $\mathrm{R}$ & $\geq 256$ & $\mathrm{R}$ \\
\hline HP 3 B & $\geq 240$ & $\geq 4$ & $\mathrm{R}$ & $\mathrm{R}$ & $\mathrm{R}$ & $\geq 256$ & $\mathrm{R}$ \\
\hline HP 4 A & $\geq 240$ & $\mathrm{R}$ & $\geq 256$ & $\mathrm{R}$ & $\mathrm{R}$ & $\geq 256$ & $\mathrm{R}$ \\
\hline HP 4 B & $\geq 240$ & $\mathrm{R}$ & $\geq 256$ & $\mathrm{R}$ & $\mathrm{R}$ & $\geq 256$ & $\mathrm{R}$ \\
\hline HP 5 & $\mathrm{R}$ & $\mathrm{R}$ & $\mathrm{R}$ & $\mathrm{R}$ & $\mathrm{R}$ & $\geq 256$ & $\mathrm{R}$ \\
\hline $\begin{array}{c}\text { Operation theatre } \\
\text { swab OT } 1\end{array}$ & $\geq 240$ & $\mathrm{R}$ & $\mathrm{R}$ & $\mathrm{R}$ & $\mathrm{R}$ & $\geq 256$ & $\mathrm{R}$ \\
\hline OT 3A & $\geq 256$ & $\geq 4$ & $\geq 256$ & $\mathrm{R}$ & $\mathrm{R}$ & $\geq 256$ & $\mathrm{R}$ \\
\hline OT 3 B & $\geq 240$ & $\geq 4$ & $\geq 256$ & $\geq 32$ & $\mathrm{R}$ & $\geq 256$ & $\mathrm{R}$ \\
\hline Urine Sample & $\mathrm{R}$ & $\mathrm{R}$ & $\mathrm{R}$ & $\mathrm{R}$ & $\mathrm{R}$ & $\geq 256$ & $\mathrm{R}$ \\
\hline $\begin{array}{c}\text { Hospital bed sample } \\
\text { HBS } 2\end{array}$ & $\geq 240$ & $\geq 4$ & $\geq 256$ & $\mathrm{R}$ & $\geq 256$ & $\geq 256$ & $\mathrm{R}$ \\
\hline
\end{tabular}

Table 3: Minimum Inhibitory Concentrations (MICs) of antibiotic against MRSA isolates.

\begin{tabular}{|c|c|c|}
\hline ISOLATES & Samples & MRSA \\
\hline EC 1 W & Rectal swab from Women 1 & + \\
\hline EC 2 W & Rectal swab from Women 2 & N \\
\hline EC 3 W & Rectal swab from Women 3 & + \\
\hline EC 1 M & Hand swab from men 1 & $\mathrm{N}$ \\
\hline EC 2 M & Hand swab from men 2 & + \\
\hline EC 3 M & Hand swab from men 3 & + \\
\hline EC 1 C & Hand swab from child 1 & + \\
\hline EC 2 C & Hand swab from child 2 & $\mathrm{N}$ \\
\hline EC 3 C & Hand swab from child 3 & + \\
\hline EC 4 C & Hand swab from child 4 & $\mathrm{N}$ \\
\hline TFS 1 & Toilet Floor sample 1 & + \\
\hline TFS 2 & Toilet Floor sample 2 & $\mathrm{N}$ \\
\hline TFS 3 & Toilet Floor sample 3 & $\mathrm{N}$ \\
\hline TFS 4 & Toilet Floor sample 4 & $\mathrm{N}$ \\
\hline TFS 5 & Toilet Floor sample 5 & $\mathrm{N}$ \\
\hline TFS 6 & Toilet Floor sample 6 & \\
\hline
\end{tabular}




\section{International Journal of Zoology and Animal Biology}

\begin{tabular}{|c|c|c|}
\hline TFS 7 & Toilet Floor sample 7 & + \\
\hline TFS 8 & Toilet Floor sample 8 & $\mathrm{~N}$ \\
\hline TFS 9 & Toilet Floor sample 9 & $\mathrm{~N}$ \\
\hline FS 1 & Floor sample 1 & $\mathrm{~N}$ \\
\hline FS 2 & Floor sample 2 & + \\
\hline FS 3 & Floor sample 3 & $\mathrm{~N}$ \\
\hline FS 4 & Floor sample 4 & $\mathrm{~N}$ \\
\hline HP 1 & Staff hand swab HP 1 & + \\
\hline HP 2 & Staff hand swab HP 2 & + \\
\hline HP 3 & Staff hand swab HP 3 & + \\
\hline HP4 & Staff hand swab HP 4 & + \\
\hline HP 5 & Staff hand swab HP 5 & + \\
\hline OT 1 & Operation theatre swab OT 1 & + \\
\hline OT 2 & Operation theatre swab OT 2 & $\mathrm{~N}$ \\
\hline OT 3 & Operation theatre swab OT 3 & + \\
\hline OT 4 & Operation theatre swab OT 4 & $\mathrm{~N}$ \\
\hline OT 5 & Operation theatre swab OT 5 & $\mathrm{~N}$ \\
\hline Urine Sample & Urine sample from Women & + \\
\hline HBS 1 & Hospital bed sample 1 & $\mathrm{~N}$ \\
\hline HBS 2 & Hospital bed sample 2 & + \\
\hline
\end{tabular}

Table 4: Samples collected for the screening of MRSA.

Exactly, 6 isolates $(24.0 \%)$ were amplified with the product size of $320 \mathrm{bp}$ with $\mathrm{MecA}$ gene and the other isolates were of S.aureus except one, coagulase negative Staphylococci. Similarly, Zinzendorf, et al. [7] was able to detect mecA genes in $19.3 \%$ military hospital isolates. In contrast to present study, Aziz, et al. [36] was able to detect $m e c A$ gene in $71.05 \%$ of MRSA isolates in Iraq.

The present study reports the presence of multidrug resistant MRSA in the hospital settings could pose the serious concern over the public health issues [37]. This study further suggests that strict hygienic measures such hand wash, judicious antibiotic use and antimicrobial testing's before prescription etc., could be followed for the effective implementation of antimicrobial stewardship program for the control of AMR pathogens in the hospital settings.

\section{Acknowledgment}

This research work is carried out for the partial fulfilment of B. Tech- Biotechnology at Veltech Hightech Dr. Rangarajan Dr. Sakunthala Engineering College, Avadi, Chennai-62., Tamil Nadu, and India. The authors thankfully acknowledge the Director, ICAR- RC of CMFRI and CIFT, Veraval, and the District Hospital, Veraval, Gujarat for providing the necessary facilities to carry out the research work.

\section{References}

1. Dye C (2014) After 2015: infectious diseases in a new era of health and development. Phil Trans R Soc B 369(1648): 20130426.

2. Bala Murali KP, Rama Lakshmi K, Sudha Vani TMS, Lakshmi N (2016) Prevalence of Methicillin Resistant Staphylococcus aureus in a Tertiary Care Hospital. IOSR J appl of dent Med Sci 15(5): 29-31.

3. Murray PR, Baron EJ, Jorgensen JH, Landry ML, Pfaller MA, et al. (2003) Manual of Clinical Microbiology $8^{\text {th }}$ (Edn.), Herdon, VA, United States of America.

4. Fleming DM, Elliot AJ, Kendall H (2007) Skin infections and antibiotic prescribing: a comparison of surveillance and prescribing data. Br J Gen Prac 57(540): 569-573.

5. Kroneberg A, Koenig S, Droz S, Muhlemann K (2011) Active surveillance of antibiotic resistance prevalence in urinary tract and skin infections in the outpatient setting. Clin Microbiol Infect 17(12): 845-851.

6. Kuehnert MJ, Kruson Moran D, Hill HA, McQuillan G, McAllister SK, et al. (2006) Prevalence of Staphylococcus aureus nasal colonization in the
Sivaraman GK, et al. Occurrence of Methicillin Resistant Staphylococcus Aureus in Emerging Tertiary Care Hospital, Veraval, Gujarat, India. Int J Zoo Animal Biol 2019, 2(5): 000177. 


\section{International Journal of Zoology and Animal Biology}

United States 2001-2002. J Infect Dis 193(2): 172179.

7. Zinzendorf NY, Krizo A, Baba Moussa L, Edoh V, Loukou YG (2012) Molecular Characteristics of Staphylococcus aureus from Military Hospital in Abidjan, Cote d'Ivoire. Bull Environ Pharmacol Life Sci 1(7): 54-58.

8. Katayama Y, Ito T, Hiramatsu K (2000) A new class of genetic element, Staphylococcus cassette chromosome mec, encodes methicillin resistance in Staphylococcus aureus. Antimicrob. Agents Chemother 44(6): 1549-1555.

9. Sachdev D, Amladi S, Nataraj G, Baveja S, Kharkar V, et al. (2003) An outbreak of Methicillin-resistant Staphylococus aureus (MRSA) infection in dermatology indoor patients. Indian J Dermatol Venereol Leprol 69(6): 377-380.

10. Tiemersma EW, Bronzwaer SL, Lyytikäinen O, Degener JE, Schrijnemakers P, et al. (2004) Methicillin-resistant Staphylococcus aureus in Europe 1999-2002. Emerg Infect Dis 10(9): 1627-1634.

11. Jain R, Kralovic SM, Evans ME, Ambrose M, Simbartl LA, et al. (2011) Veterans Affairs initiative to prevent methicillin-resistant Staphylococcus aureus infections. N Engl J Med 364(15): 1419-1430.

12. Asghar AH (2014) Molecular characterization of methicllin resistant Staphylococcus aureus isolated from tertiary care hospitals. Pak J Med Sci 30(4): 698702 .

13. Kim J, Ferrato C, Golding GR, Mulvey MR, Simmonds KA, et al. (2011) Changing epidemiology of methicillin resistant Staphylococcus aureus in Alberta, Canada: Population based surveillance 2005-2008. Epidemiol Infect 139(7): 1009-1018.

14. Simor AE, Gilbert NL, Gravel D, Mulvey MR, Bryce E, et al. (2010) Methicillin resistant Staphylococcus aureus colonization or infection in Canada. National Surveillance and Changing Epidemiology 1995-2007. Infect Control Hosp Epidemiol 31(4): 348-35.

15. Patel AK, Patel KK, Patel KR, Shah S, Dileep P (2010) Time trends in the epidemiology of microbial infections at a tertiary care centre in west India over last 5 years. J Assoc Physicians India 58(S1): 37-40.
16. Mallick SK, Basak S (2010) MRSA too Many Hurdles to Overcome: A Study from Central India. Trop Doct 40(2): 108-110.

17. Rubali SM, Akshay RK, Nitin AA, Sarika PK (2014) Prevalence of Methicillin Resistant Staphylococcus aureus in tertiary care hospital Central India. Int J Curr Microbiol App Sci 3(10): 582-586.

18. Murugan K, Kavitha K, Al Sohaibani S (2015) Rifampicin resistance among multi-resistant MRSA clinical isolates from Chennai, India, and their molecular characterization. Genet Mol Res 14: 27162725.

19. Bhattacharya S (2011) Is screening patients for antibiotic-resistant bacteria justified in the Indian context?. Indian J Med Microbiol 29(3): 213-217.

20. WHO (2014) Antimicrobial resistance: global report on surveillance Geneva: World Health Organization, Geneva.

21. Sivaraman GK, Deesha V, Prasad MM, Jha AK, Visnuvinayagam S, et al. (2016) Incidence of community acquired Methicillin-resistant Staphylococcus aureus (CA-MRSA) in seafood and its environment, Gujarat, India. Int J Recent Sci Res $7(11):$ 14279-14282.

22. Sivaraman GK, Deesha V, Visnuvinayagam S, Prasad MM, Ravishankar CN (2017) Draft Genome sequence of a Methicillin Resistant Staphylococci (Sequence Type 1) from seafood, India. Genome Announc 5(34): e00776-17.

23. ISO (2003) Microbiology of food and animal feeding stuffs Horizontal method for the enumeration of coagulase-positive staphylococci (Staphylococcus aureus and other species) Part 1: Technique using Baird-Parker agar medium; Part 2: Technique using rabbit plasma fibrinogen medium \& Part 3: Detection and MPN technique for low numbers. ISO, Geneva.

24. CLSI (2015) Methods for dilution antimicrobial susceptibility tests for bacteria that grow aerobically; Approvd standard-Tenth Edition. CLSI document M07-A10. Wayne, PA: Clinical Laboratory Standards Insittute.

25. Fombda BA, Thokar MA, Bashir G, Khan A, Kour, et al. (2014) Prevalence and genotypic relatedness of
Sivaraman GK, et al. Occurrence of Methicillin Resistant Staphylococcus Aureus in Emerging Tertiary Care Hospital, Veraval, Gujarat, India. Int J Zoo Animal Biol 2019, 2(5): 000177. 
methicillin resistant Staphylococcus aureus in a tertiary care hospital. J Postgrad Med 60(4): 386-389.

26. Kesah C, Ben Redjeb S, Odugbemi TO, Boye CS, Dosso $M$, et al. (2003) Prevalence of methicillinresistant Staphylococcus aureus in eight African hospitals and Malta. Clin Microbiol Infect 9(2): 153156.

27. Fluit AC, Wielders CL, Verhoef J, Schmitz FJ (2001) Epidemiology and susceptibility of 3051 Staphylococcus aureus isolates from 25 university hospitals participating in the European sentry study. J Clin Microbiol 39(10): 3727-3732.

28. Fridkin SK, Gaynes RP (1999) Antimicrobial resistance in intensive care units. Clin Chest Med 20(2): 303-316.

29. Vysakh PR, Kandasamy S, Prabhavathi RM (2015) Speciation of clinically significant coagulase negative Staphylococci and their antibiotic resistant patterns in a tertiary care hospital. Int J Current Microbiol App Sci 4: 704-709.

30. Ferreira JS, Costa WLR, Cerqueira ES, Carvalho JS, Oliveira LC, et al. (2014) Food handler-associated methicillin-resistant Staphylococcus aureus in public hospitals in Salvador. Brazilian J of Food Control 37: 395-400.

31. Gutierrez D, Delgado S, Sanchez DV, Martinez B, Cabo ML, et al. (2102) Incidence of Staphylococcus aureus and analysis of associated bacterial communities on food industry surfaces. Appl Environ Microbiol 78(24): 8547-8554.

32. Hunter PA, Dawson S, French GL, Goossens H, Hawkey PM, et al. (2010) Antimicrobial-resistant pathogens in animals and man: Prescribing, practices and policies. J Antimicro Chemo 65(S1): i3-i17.

33. Tiwari HK, Sapkota D, Sen MR (2008) High prevalence of multidrug-resistant MRSA in a tertiary care hospital of northern India. Infect Drug Resist 1: 57-61.

34. Styers D, Sheehan DJ, Hogan P, Sahm DF (2006) Laboratory-based surveillance of current antimicrobial patterns and trends among Staphylococcus aureus: 2005 status in the United States. Ann Clinl Microbiol Antimicrobl 5: 2.

35. Murugadas V, Toms CJ, Reshmi K, Lalitha KV (2016) Prevalence of methicillin resistant Staphylococcus aureus in selected seafood markets and aquaculture farms in Kerala, south-west coast of India. Indian J Fish 63(4): 150-153.

36. Aziz M, Kiil K, Cirković I, Udo EE, del Campo R, et al. (2014) Origin and evolution of European communityacquired methicillin-resistant Staphylococcus aureus. MBio 5(5): e01044-14.

37. Bauer AW, Kirby Sherris WMMJC, Turck M (1966) Antibiotic susceptibility testing by a standardized single disk method. Am J Clin Pathol 45(4): 493-496. 